\title{
Investigation of the $l$-Phenylacetylcarbinol Process to Substituted Benzaldehydes of Interest
}

\author{
Authors: Kerrie-Anne Maroney ${ }^{\mathrm{a} *}$; Peter Culshhaw ${ }^{\mathrm{b}}$; Urs D. Wermuth ${ }^{\mathrm{a}, \mathrm{b}}$ and \\ Sarah Cresswell ${ }^{\mathrm{a}}$ \\ ${ }^{\text {a }}$ Queensland Health Forensic and Scientific Services (QHFSS), 39 Kessels Rd, Brisbane \\ Australia \\ b School of Biomolecular and Physical Sciences, Griffith University, Brisbane Australia
}

* Corresponding author contact details:

Forensic Chemistry, Queensland Health Forensic and Scientific Services, 39 Kessels Rd, Brisbane 4108, Queensland, Australia

Tel: +61 732749031

E-mail: kerrie anne_maroney@health.qld.gov.au 


\begin{abstract}
The large scale industrial manufacture of the nasal decongestant pseudoephedrine is typically carried out by the reductive amination of $l$-phenylacetylcarbinol (l-PAC), which in turn is produced via the biotransformation of benzaldehyde using yeast. In recent years there has been increasing legislative control of the supply of pseudoephedrine due to it being diverted for the clandestine production of methylamphetamine and there is some evidence that a number of clandestine drug laboratory chemists have considered the application of the l-PAC process to manufacture their own pseudoephedrine. This work examined the use of a number of substituted benzaldehydes for the manufacture of the corresponding substituted $l$ PAC analogue followed by reductive amination to the corresponding substituted pseudoephedrine/ephedrine analogues. These substituted pseudoephedrine/ephedrine analogues were either reduced or oxidised to determine the feasibility of producing the corresponding methylamphetamine or methcathinone analogues. As a result, the $l$-PAC process was identified as a viable route for synthesis of substituted methylamphetamines and methcathinones.
\end{abstract}

Keywords $l$-PAC, Biotransformation, Methamphetamine, Clandestine, Ephedrine

\title{
Introduction
}

The $l$-Phenylacetylcarbinol ( $l$-PAC) process is a biotransformation process using the fungus yeast. The mechanism, which was initially investigated by Neuberg et al. ${ }^{1,2}$, involves glycolysis of glucose to produce pyruvic acid which is then decarboxylated by pyruvate decarboxylase to produce acetaldehyde. The resulting acetaldehyde then undergoes a condensation reaction with benzaldehyde to produce $l$-PAC $[(R)-1$ hydroxy-1-phenylpropan-2-one]. During this process, by-products are formed due to the action of alcohol dehydrogenase on benzaldehyde and $l$-PAC resulting in benzyl alcohol and $(1 R, 2 S)$-1-phenylpropan-1,2-diol (PAC-diol) respectively. ${ }^{3,4}$ (Refer to Scheme 1) 


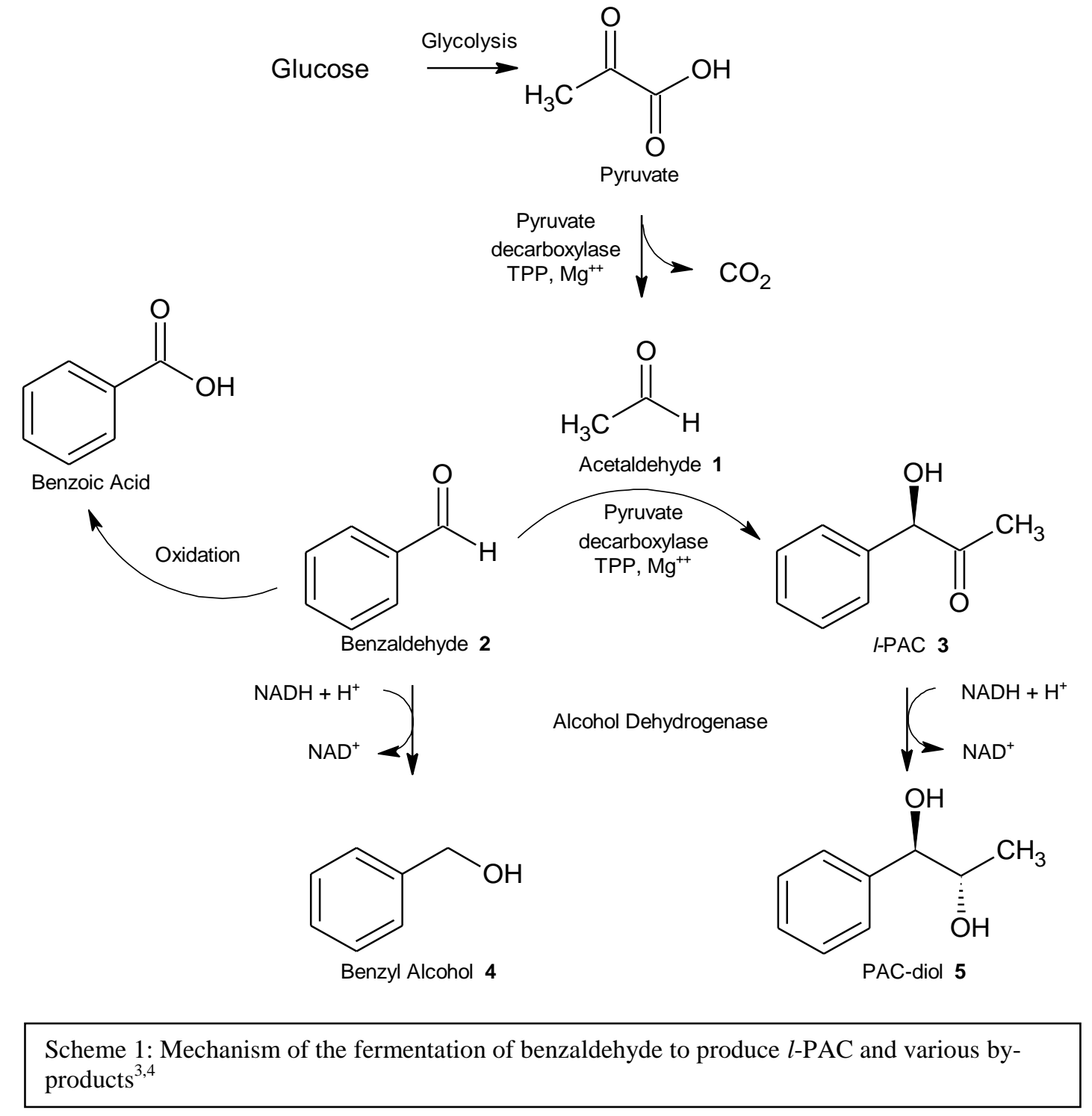

The $l$-PAC process has previously been employed by the pharmaceutical industry due to the ease with which $l$-PAC can be chemically converted to pseudoephedrine/ephedrine. In recent years, a number of clandestine drug laboratories have been located which have exploited the commercial process for the production of pseudoephedrine/ephedrine for use in the manufacture of methylamphetamine ${ }^{3}$.

Global controls over the supply of pseudoephedrine as a potential illicit drug precursor has heightened the possibility that this process will gain increased importance in illicit drug production. This process has dual applicability in that the pseudoephedrine/ephedrine produced by this process can be employed for both methylamphetamine and methcathinone production. 
The work presented here aimed to investigate the $l$-PAC process as a viable manufacturing pathway to produce a variety of substituted methylamphetamines and methcathinones and hence identify the potential emerging precursor chemicals for substituted methylamphetamine and methcathinone analogues.

\section{Materials and Methods}

\subsection{Materials}

Piperonal (3,4-methylenedioxybenzaldehyde), acetaldehyde, benzaldehyde, hypophosphorous acid, $50 \% \mathrm{w} / \mathrm{w}$, sodium bicarbonate, sodium carbonate, sodium chloride and trisodium citrate were purchased from Sigma-Aldrich. 4(Methylthio)benzaldehyde, 4-fluorobenzaldehyde and sodium borohydride were purchased from Alfa Aesar. 4-Methylbenzaldehyde, 4-anisaldehyde (4methoxybenzaldehyde), Celite 545 (particle size $0.02-0.1 \mathrm{~mm}$ ) and analytical grade ethanol were purchased from Merck. Citric Acid Monohydrate, ethyl acetate, hydrochloric acid 32\% and sodium hydroxide were purchased from Ajax Fine Chemicals. Chloroform, dichloromethane and diethyl ether were purchased from Macron Fine Chemicals, J.T.Baker and BioLab respectively. Iodine, methylamine aqueous solution $40 \%$, sodium dichromate dihydrate and sulphuric acid were purchased from Asia Pacific Specialty Chemicals LTD, Prolabo, Fluka and BDH respectively. Sodium hydrosulfite and sodium sulphate anhydrous granular were purchased from Chem-Supply. All reagents and solvents purchased were of analytical grade and not further purified before use. Dextose (glucose), manufactured by Brigalow Natural Products and Instant Dried, Premium Bakers' Yeast (species Saccharomyces cerevisiae), manufactured by Lowan Whole Foods was purchased from a local supermarket.

\subsection{Instrumentation}

Gas Chromatography-Mass Spectrometry (GC-MS) analyses were performed on an Agilent HP-6890N Network GC System using an Agilent HP-5MS capillary column (30 m x $0.25 \mu \mathrm{m}$ ) fitted with an Agilent HP-5973 mass selective detector. The carrier gas was helium at a constant flow of $1.0 \mathrm{~mL} / \mathrm{min}$ and a split ratio of $25: 1$ with an injection volume of $0.2 \mu \mathrm{L}$. The injector temperature was set to $100^{\circ} \mathrm{C}$, with an initial oven temperature of $100^{\circ} \mathrm{C}$ held for $1 \mathrm{~min}$, then ramped at $30^{\circ} \mathrm{C} / \mathrm{min}$ to $280^{\circ} \mathrm{C}$ and 
held there for 10 mins. The mass selective detector operated between $m / z=40$ and 450 in electron impact mode with an ionization energy of $70 \mathrm{eV}$.

Gas Chromatography-Vapour Phase Infrared (GC-IRD) analyses were performed on an Agilent HP-7890A GC System using an Agilent HP-5MS capillary column (30 m x $0.25 \mu \mathrm{m}$ ) fitted with an ASAP IRD II Infrared Detector. The carrier gas was helium at a constant flow of $4.2 \mathrm{~mL} / \mathrm{min}$. The injector was set at a pulsed split of 24 psi for 2 mins with a split ratio of 1:1 and an injection volume of $2 \mu \mathrm{L}$. The injector temperature was set to $100^{\circ} \mathrm{C}$, with an initial oven temperature of $100^{\circ} \mathrm{C}$ held for 2 mins, then ramped at $20^{\circ} \mathrm{C} / \mathrm{min}$ to $280^{\circ} \mathrm{C}$ and held there for $8 \mathrm{mins}$. The temperature of the transfer lines and light pipe were kept at $250^{\circ} \mathrm{C}$ and the IRD II's scanning range was set to $4000-500 \mathrm{~cm}^{-1}$.

Nuclear Magnetic Resonance (NMR) analysis was carried out using a Varian 400 $\mathrm{MHz}$ Unity INOVA spectrometer operating at $400 \mathrm{MHz}\left({ }^{1} \mathrm{H}\right)$ and $100 \mathrm{MHz}\left({ }^{13} \mathrm{C}\right)$. Samples were run in a mixed solvent system of $\mathrm{d}^{6} \mathrm{DMSO}$ and $\mathrm{CDCl}_{3}$ at $298 \mathrm{~K}$. ${ }^{1} \mathrm{H}$ spectra were referenced to the $\mathrm{d}^{6} \mathrm{DMSO}$ solvent residual taken as $2.49 \mathrm{ppm}$ and ${ }^{13} \mathrm{C}$ spectra were referenced to the $\mathrm{d}^{6} \mathrm{DMSO}$ solvent residual taken at $39.50 \mathrm{ppm}$ at the temperature quoted.

\subsection{General Fermentation Procedure}

Yeast (44 g) and glucose (310 mmol) were added to a beaker and placed in a water bath heated to $30^{\circ} \mathrm{C}$. To this, $500 \mathrm{~mL}$ of a $0.1 \mathrm{M}$ citrate buffer $(\mathrm{pH}$ 5) consisting of $7.35 \mathrm{~g}$ trisodium citrate and $5.25 \mathrm{~g}$ citric acid in deionised water was added. The broth was stirred for 40 mins before a substituted benzaldehyde $(25 \mathrm{mmol})$ in $5 \mathrm{~mL}$ ethanol and acetaldehyde $(30 \mathrm{mmol})$ was added to the broth. After being left to ferment for approximately $60 \mathrm{mins}$, the broth was filtered through Celite and extracted with ethyl acetate $(3 \times 100 \mathrm{~mL})$. Emulsions in the extract were broken through the use of a saturated sodium chloride solution, dried over anhydrous sodium sulphate, filtered and evaporated. The crude reaction product was dissolved in chloroform and analysed using GC-MS and GC-IRD. Specific quantities of each reagent and fermentation times can be found in Table 1. Samples were deliberately not purified between each reaction stage to allow reaction specific by-products as well as the product of interest to carry through to the next stage. This would most 
likely mimic those conditions found in a clandestine drug laboratory where precursor materials from each stage are not purified greatly from one step to the next.

\begin{tabular}{|c|c|c|c|c|c|}
\hline \multicolumn{2}{|c|}{ Starting Material } & \multirow{2}{*}{$\begin{array}{l}\text { Acetaldehyde } \\
(\mathrm{g})\end{array}$} & \multirow{2}{*}{$\begin{array}{l}\text { Yeast } \\
(\mathrm{g})\end{array}$} & \multirow{2}{*}{$\begin{array}{l}\text { Glucose } \\
\text { (g) }\end{array}$} & \multirow{2}{*}{$\begin{array}{c}\text { Filtered } \\
\text { After } \\
\text { (mins) }\end{array}$} \\
\hline Substituted Benzaldehyde & Grams & & & & \\
\hline Benzaldehyde & $\begin{array}{c}3.218 \\
(30 \mathrm{mmol})\end{array}$ & $\begin{array}{c}2.706 \\
(61 \mathrm{mmol})\end{array}$ & 44.750 & $\begin{array}{c}55.308 \\
(307 \mathrm{mmol})\end{array}$ & 80 \\
\hline $\begin{array}{l}\text { 3,4-Methylenedioxy- } \\
\text { benzaldehyde }\end{array}$ & $\begin{array}{c}3.159 \\
(21 \mathrm{mmol})\end{array}$ & $\begin{array}{c}1.039 \\
(24 \mathrm{mmol})\end{array}$ & 44.325 & $\begin{array}{c}55.821 \\
(310 \mathrm{mmol})\end{array}$ & 30 \\
\hline 4-Methoxybenzaldehyde & $\begin{array}{c}3.259 \\
(24 \mathrm{mmol})\end{array}$ & $\begin{array}{c}1.201 \\
(27 \mathrm{mmol})\end{array}$ & 44.427 & $\begin{array}{c}55.845 \\
(310 \mathrm{mmol})\end{array}$ & 60 \\
\hline 4-Fluorobenzaldehyde & $\begin{array}{c}3.403 \\
(27 \mathrm{mmol})\end{array}$ & $\begin{array}{c}1.268 \\
(29 \mathrm{mmol})\end{array}$ & 44.729 & $\begin{array}{c}55.431 \\
(308 \mathrm{mmol})\end{array}$ & 60 \\
\hline 4-Methylbenzaldehyde & $\begin{array}{c}3.347 \\
(28 \mathrm{mmol})\end{array}$ & $\begin{array}{c}1.287 \\
(29 \mathrm{mmol})\end{array}$ & 44.564 & $\begin{array}{c}55.713 \\
(309 \mathrm{mmol})\end{array}$ & 50 \\
\hline $\begin{array}{l}\text { 4-(Methylthio)- } \\
\text { benzaldehyde }\end{array}$ & $\begin{array}{c}3.111 \\
(20 \mathrm{mmol})\end{array}$ & $\begin{array}{c}1.863 \\
(42 \mathrm{mmol})\end{array}$ & 44.212 & $\begin{array}{c}55.913 \\
(310 \mathrm{mmol})\end{array}$ & 40 \\
\hline
\end{tabular}

\subsection{Bisulfite Adduct Purification prior to NMR Analysis}

Whilst our intent was to only perform minimal purification in order to observe reaction marker by-products at each stage, the corresponding $l$-PAC products were purified prior to NMR analysis by the bisulfite adduct purification technique previously employed by Neuberg and Ohle ${ }^{5}$. Each crude sample was taken up in 10 $\mathrm{mL}$ diethyl ether and extracted with saturated sodium carbonate solution $(2 \times 5 \mathrm{~mL})$ to remove excess benzoic acid. The diethyl ether layer was then washed with deionised water $(2 \times 5 \mathrm{~mL})$, the aqueous extracts combined and further extracted with diethyl ether $(2 \times 5 \mathrm{~mL})$. The diethyl ether extracts were then combined and 15 $\mathrm{mL}$ of a freshly made saturated sodium hydrosulfite solution was added. The solution was left to react for 60 mins, being shaken every few minutes. Any benzyl alcohol in the sample was then removed through extraction with diethyl ether $(3 \times 10$ $\mathrm{mL}$ ). To the retained aqueous layer, solid sodium bicarbonate was added until the 
evolution of carbon dioxide ceased. This aqueous layer was then extracted with diethyl ether ( $3 \times 10 \mathrm{~mL}$ ), dried over anhydrous sodium sulphate, filtered and evaporated on a rotary evaporator. A sample of each product was dissolved in chloroform and assessed for purity by GC-MS prior to NMR analysis.

\subsection{Reductive Amination Procedure}

Using quantities as outlined in Table 2, ethanol and methylamine (40\% in water) was added to each sample of crude $l$-PAC analogue and left to react at room temperature for 30 mins, to allow imine formation. The solution was cooled in an ice bath and reduced using sodium borohydride for 90 mins. The solution was then basified with a $10 \%$ sodium hydroxide solution (approximately $10 \mathrm{~mL}$ ) and extracted with dichloromethane $(3 \times 10 \mathrm{~mL})$. The combined extracts were dried over anhydrous sodium sulphate, filtered and evaporated. A sample of each product was dissolved in chloroform and analysed by GC-MS and GC-IRD.

Excess benzyl alcohol that had formed as a by-product was then removed through an acid-base extraction. The sample was acidified using $10 \mathrm{~mL}$ of $10 \%$ hydrochloric acid, shaken briefly and extracted with dichloromethane $(3 \times 10 \mathrm{~mL})$ to remove the neutral components. The aqueous layer was then basified with a $10 \%$ solution of sodium hydroxide in water and extracted with dichloromethane $(3 \times 10 \mathrm{~mL})$. The combined extracts were dried over anhydrous sodium sulphate, filtered and evaporated on a rotary evaporator. A sample of each product was collected, dissolved in chloroform and analysed by GC-MS and GC-IRD. Specific quantities of each reagent can be found in Table 2 . 
Table 2: Reagents used in the reductive amination of each $l$-PAC analogue.

\begin{tabular}{|c|c|c|c|c|}
\hline \multicolumn{2}{|c|}{ Starting Material } & \multirow[b]{2}{*}{$\begin{array}{l}\text { Methylamine } \\
\quad(\mathrm{mL})\end{array}$} & \multirow[b]{2}{*}{$\begin{array}{c}\text { Ethanol } \\
(\mathrm{mL})\end{array}$} & \multirow{2}{*}{$\begin{array}{c}\text { Sodium } \\
\text { Borohydride } \\
(\mathrm{g})\end{array}$} \\
\hline $\begin{array}{l}\text { Crude } l \text {-PAC } \\
\text { analogues }\end{array}$ & $\begin{array}{c}\text { Grams } \\
\text { (\% l-PAC } \\
\text { Analogue) }\end{array}$ & & & \\
\hline$l$-PAC & $\begin{array}{c}6.672 \\
(21 \%) \\
(9 \mathrm{mmol})\end{array}$ & $\begin{array}{c}5.6 \\
(65 \mathrm{mmol})\end{array}$ & 8.4 & $\begin{array}{c}3.934 \\
(104 \mathrm{mmol})\end{array}$ \\
\hline $\begin{array}{c}\text { 3,4-Methylenedioxy- } \\
\text { l-PAC }\end{array}$ & $\begin{array}{c}15.773 \\
(10 \%) \\
(8 \mathrm{mmol})\end{array}$ & $\begin{array}{c}2.5 \\
(29 \mathrm{mmol})\end{array}$ & 15 & $\begin{array}{c}2.045 \\
(54 \mathrm{mmol})\end{array}$ \\
\hline 4-Methoxy-l-PAC & $\begin{array}{c}10.769 \\
(19 \%) \\
(11 \mathrm{mmol}) \\
\end{array}$ & $\begin{array}{c}1.5 \\
(17 \mathrm{mmol})\end{array}$ & 15 & $\begin{array}{c}0.900 \\
(24 \mathrm{mmol})\end{array}$ \\
\hline 4-Fluoro-l-PAC & $\begin{array}{c}10.473 \\
(23 \%) \\
(14 \mathrm{mmol})\end{array}$ & $\begin{array}{c}2.5 \\
(29 \mathrm{mmol})\end{array}$ & 15 & $\begin{array}{c}1.577 \\
(42 \mathrm{mmol})\end{array}$ \\
\hline 4-Methyl- $l$-PAC & $\begin{array}{c}2.025 \\
(14 \%) \\
(2 \mathrm{mmol})\end{array}$ & $\begin{array}{c}2 \\
(23 \mathrm{mmol})\end{array}$ & 6 & $\begin{array}{c}1.726 \\
(46 \mathrm{mmol})\end{array}$ \\
\hline 4-Methylthio- $l$-PAC & $\begin{array}{c}11.526 \\
(14 \%) \\
(8 \mathrm{mmol})\end{array}$ & $\begin{array}{c}3 \\
(35 \mathrm{mmol})\end{array}$ & 20 & $\begin{array}{c}3.185 \\
(84 \mathrm{mmol})\end{array}$ \\
\hline
\end{tabular}

\subsection{Reduction Procedure}

To each of the pseudoephedrine/ephedrine analogues a mixture of iodine in hypophosphorous acid was added. Each solution was refluxed for 120 mins and allowed to cool to room temperature. Each solution was basified with a saturated sodium carbonate solution and extracted with chloroform (3 x $10 \mathrm{~mL})$. The combined extracts were dried over anhydrous sodium sulphate, filtered and evaporated on a rotary evaporator. A sample of each product was dissolved in chloroform and analysed by GC-MS and GC-IRD. Specific quantities of each reagent can be found in Table 3 . 
Table 3: Reagents used in the reduction of each pseudoephedrine/ephedrine analogue.

\begin{tabular}{|c|c|c|c|}
\hline \multicolumn{2}{|c|}{ Starting Material } & \multirow[b]{2}{*}{$\begin{array}{l}\text { Iodine } \\
(\mathrm{g})\end{array}$} & \multirow[b]{2}{*}{$\begin{array}{l}\text { Hypophosphorous } \\
\text { Acid } \\
(\mathrm{mL})\end{array}$} \\
\hline $\begin{array}{c}\text { Crude } \\
\text { Pseudoephedrine/ } \\
\text { ephedrine } \\
\text { Analogue }\end{array}$ & $\begin{array}{c}\text { Grams } \\
\text { (\% Pseudoephedrine/ } \\
\text { ephedrine } \\
\text { Analogue) }\end{array}$ & & \\
\hline Pseudoephedrine/ephedrine & $\begin{array}{c}0.497 \\
(88 \%) \\
(3 \mathrm{mmol})\end{array}$ & $\begin{array}{c}0.496 \\
(2 \mathrm{~mol})\end{array}$ & $\begin{array}{c}2 \\
(37 \mathrm{mmol})\end{array}$ \\
\hline $\begin{array}{l}\text { 3,4-Methylenedioxy- } \alpha-[1- \\
\text { (methylamino)ethyl]- } \\
\text { benzenemethanol }\end{array}$ & $\begin{array}{c}0.531 \\
(29 \%) \\
(0.7 \mathrm{mmol})\end{array}$ & $\begin{array}{c}0.456 \\
(2 \mathrm{~mol})\end{array}$ & $\begin{array}{c}2 \\
(37 \mathrm{mmol})\end{array}$ \\
\hline $\begin{array}{l}\text { 4-Methoxy- } \alpha-[1- \\
\text { (methylamino)ethyl]- } \\
\text { benzenemethanol }\end{array}$ & $\begin{array}{c}0.201 \\
(23 \%) \\
(0.2 \mathrm{mmol})\end{array}$ & $\begin{array}{c}0.507 \\
(2 \mathrm{~mol})\end{array}$ & $\begin{array}{c}2 \\
(37 \mathrm{mmol})\end{array}$ \\
\hline $\begin{array}{c}\text { 4-Fluoro- } \alpha-[1- \\
\text { (methylamino)ethyl]- } \\
\text { benzenemethanol }\end{array}$ & $\begin{array}{c}0.83 \\
(62 \%) \\
(3 \mathrm{mmol})\end{array}$ & $\begin{array}{c}0.959 \\
(4 \mathrm{~mol})\end{array}$ & $\begin{array}{c}2 \\
(37 \mathrm{mmol})\end{array}$ \\
\hline $\begin{array}{c}\text { 4-Methyl- } \alpha-[1- \\
\text { (methylamino)ethyl]- } \\
\text { benzenemethanol }\end{array}$ & $\begin{array}{c}0.192 \\
(32 \%) \\
(0.3 \mathrm{mmol})\end{array}$ & $\begin{array}{c}0.103 \\
(0.4 \mathrm{mmol})\end{array}$ & $\begin{array}{c}2 \\
(37 \mathrm{mmol})\end{array}$ \\
\hline $\begin{array}{l}\text { 4-Methylthio- } \alpha-[1- \\
\text { (methylamino)ethyl]- } \\
\text { benzenemethanol }\end{array}$ & $\begin{array}{c}0.061 \\
(45 \%) \\
(0.1 \mathrm{mmol})\end{array}$ & $\begin{array}{c}0.188 \\
(0.7 \mathrm{mmol})\end{array}$ & $\begin{array}{c}2 \\
(37 \mathrm{mmol})\end{array}$ \\
\hline
\end{tabular}

\subsection{Oxidation Procedure}

Each of the crude pseudoephedrine/ephedrine analogues was dissolved in $10 \mathrm{~mL}$ of $10 \%$ sulphuric acid and placed in an ice bath. To each solution, a chilled solution of sodium dichromate in $10 \mathrm{~mL}$ of $10 \%$ sulphuric acid was added drop-wise (approximately 1 drop per 15 secs). The reaction mixture was stirred and left to react in the ice bath. After 180 mins, the reaction mixture was washed with cold chloroform to remove any aldehyde analogues which may have formed. This solution was basified with a saturated sodium carbonate solution (approximately 10 $\mathrm{mL})$ before being extracted with chloroform $(3 \times 10 \mathrm{~mL})$. The extracts were dried, filtered and evaporated. A sample of each product was collected, dissolved in 
chloroform and analysed by GC-MS and GC-IRD. Specific quantities of each reagent can be found in Table 4 .

Methcathinone has a tendency to form a pyrazine dimer when in the free base form ${ }^{6}$. For stability purposes the analogues were converted to the corresponding hydrochloride salt by the addition of hydrogen chloride gas to each of the substituted methcathinone samples in chilled isopropyl alcohol. Once the $\mathrm{pH}$ of the solution had reached $\mathrm{pH} 3$ or lower, it was placed on a heater block and the solvent evaporated under a stream of nitrogen.

\begin{tabular}{|c|c|c|}
\hline \multicolumn{2}{|c|}{ Starting Material } & \multirow{2}{*}{$\begin{array}{l}\text { Sodium } \\
\text { Dichromate } \\
\text { (g) }\end{array}$} \\
\hline $\begin{array}{l}\text { Crude Pseudoephedrine/ } \\
\text { ephedrine Analogue }\end{array}$ & $\begin{array}{c}\text { Grams } \\
\text { (\% Pseudoephedrine/ } \\
\text { ephedrine Analogue) }\end{array}$ & \\
\hline Pseudoephedrine/ephedrine & $\begin{array}{c}0.450 \\
(88 \%) \\
(2 \mathrm{mmol})\end{array}$ & $\begin{array}{c}0.613 \\
(2 \mathrm{mmol})\end{array}$ \\
\hline $\begin{array}{l}\text { 3,4-Methylenedioxy- } \alpha-[1- \\
\text { (methylamino)ethyl]- } \\
\text { benzenemethanol }\end{array}$ & $\begin{array}{c}0.843 \\
(29 \%) \\
(1 \mathrm{mmol})\end{array}$ & $\begin{array}{c}1.032 \\
(3 \mathrm{mmol})\end{array}$ \\
\hline $\begin{array}{l}\text { 4-Methoxy- } \alpha-[1- \\
\text { (methylamino)ethyl]- } \\
\text { benzenemethanol }\end{array}$ & $\begin{array}{c}0.257 \\
(23 \%) \\
(0.3 \mathrm{mmol})\end{array}$ & $\begin{array}{c}0.673 \\
(2 \mathrm{mmol})\end{array}$ \\
\hline $\begin{array}{c}\text { 4-Fluoro- } \alpha-[1- \\
\text { (methylamino)ethyl]- } \\
\text { benzenemethanol }\end{array}$ & $\begin{array}{c}0.167 \\
(55 \%) \\
(0.5 \mathrm{mmol})\end{array}$ & $\begin{array}{c}0.526 \\
(2 \mathrm{mmol})\end{array}$ \\
\hline $\begin{array}{c}\text { 4-Methyl- } \alpha-[1- \\
\text { (methylamino)ethyl]- } \\
\text { benzenemethanol }\end{array}$ & $\begin{array}{c}0.220 \\
(16 \%) \\
(0.2 \mathrm{mmol})\end{array}$ & $\begin{array}{c}0.297 \\
(1 \mathrm{mmol})\end{array}$ \\
\hline $\begin{array}{l}\text { 4-Methylthio- } \alpha-[1- \\
\text { (methylamino)ethyl]- } \\
\text { benzenemethanol }\end{array}$ & $\begin{array}{c}0.106 \\
(45 \%) \\
(0.2 \mathrm{mmol})\end{array}$ & $\begin{array}{c}0.516 \\
(2 \mathrm{mmol})\end{array}$ \\
\hline
\end{tabular}

\subsection{Results and Discussion}


The synthetic pathway employed to obtain the respective analogues is outlined in Scheme 2. Products formed during fermentation, reductive amination, reduction and oxidation of the various precursors are outlined in Tables 3, 4, 5, and 6 respectively.

\begin{tabular}{|c|c|}
\hline Substituted Benzaldehydes of Interest & $\mathbf{R}_{\mathbf{1}}$ \\
\hline Benzaldehyde & 4-H \\
\hline 3,4-Methylenedioxybenzaldehyde & 3,4-methylenedioxy \\
\hline 4-Methoxybenzaldehyde & 4-methoxy \\
\hline 4-Fluorobenzaldehyde & 4-F \\
\hline 4-Methylbenzaldehyde & 4- $\mathrm{CH}_{3}$ \\
\hline 4-(Methylthio)benzaldehyde & 4- $\mathrm{CH}_{3} \mathrm{~S}$ \\
\hline
\end{tabular}

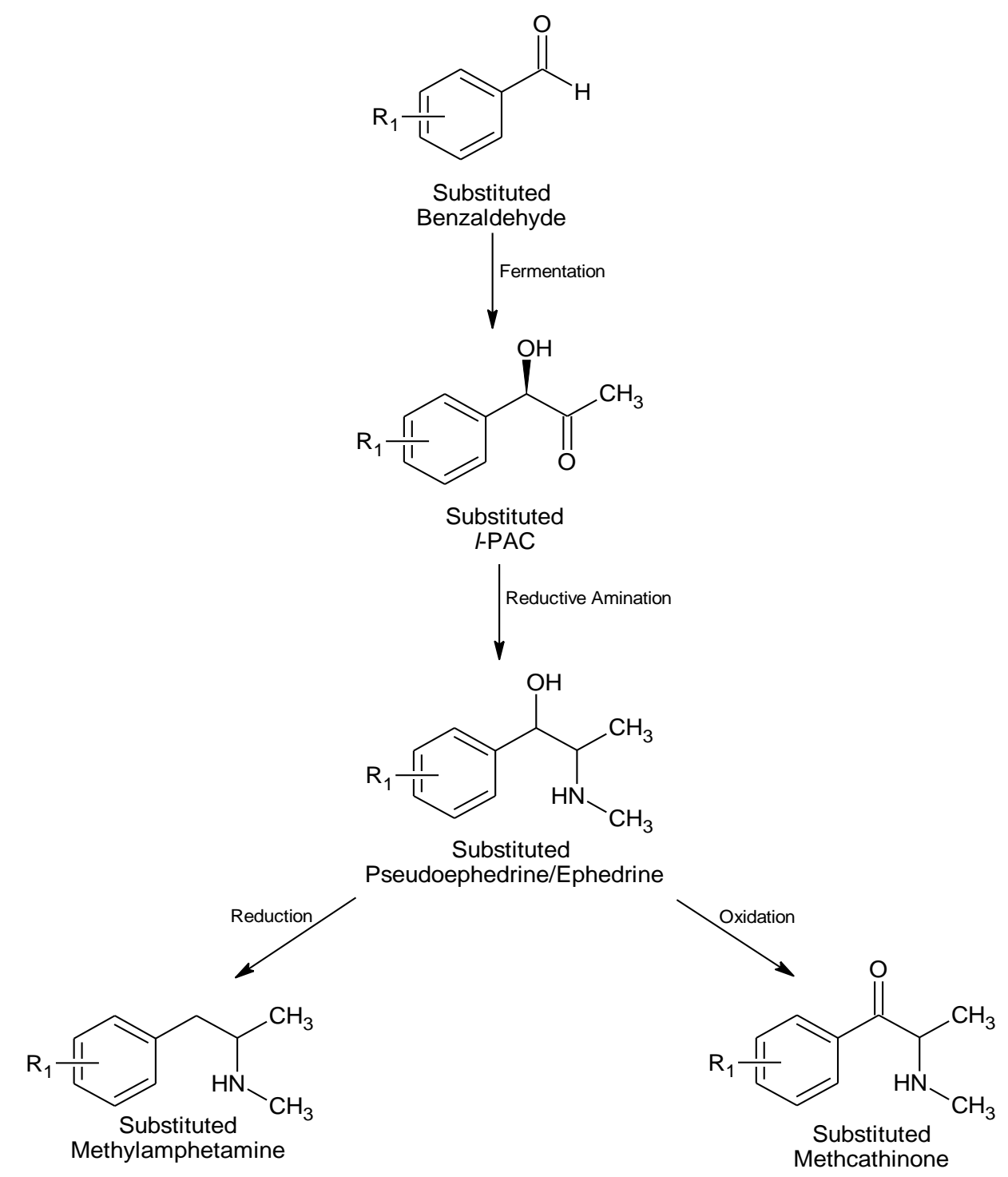

Scheme 2: The substituted benzaldehydes of interest investigated and the pathway followed. 


\subsection{Fermentation}

Initially, a number of small scale fermentations were conducted to examine the $l$ PAC process parameters using benzaldehyde. The parameters of buffer, buffer volume, temperature and acetaldehyde addition were examined. It was found that a pH $50.1 \mathrm{M}$ citrate buffer made from dissolving trisodium citrate and citric acid in deionised water gave a higher yield of $l$-PAC than when a deionised water buffer was employed. The buffer volumes were then altered to produce a benzaldehyde concentration of $12 \mathrm{~g} / \mathrm{L}$ and $6 \mathrm{~g} / \mathrm{L}$ with the $6 \mathrm{~g} / \mathrm{L}$ fermentation broth found to produce the highest $l$-PAC yield. It was also found that heating the fermentation broth to $30^{\circ} \mathrm{C}$ in a water bath as opposed to being left at room temperature contributed to an increased $l$-PAC yield. Acetaldehyde addition at various ratios of 1:1 benzaldehyde to acetaldehyde and 1:2 benzaldehyde to acetaldehyde also produced an increased $l$-PAC yield with each substituted benzaldehyde's preferred ratio noted.

Using the devised fermentation procedure each of the substituted benzaldehydes of interest underwent fermentation. The results of the fermentations are listed in Table 5. Note: Calculated percentage yields (calc'd \% yield) were found by comparing the theoretical yield of each compound with the compound's actual yield (calculated using the crude product weight and the relative (area \%) of the compound, reported during GC-MS analysis). 


\begin{tabular}{|c|c|c|c|c|c|}
\hline $\begin{array}{l}\text { Substituted } \\
\text { Benzaldehyde } \\
\text { Fermented }\end{array}$ & $\begin{array}{l}\text { l-PAC Analogue } \\
\text { Produced }\end{array}$ & $\mathrm{R}_{1}$ & $\begin{array}{l}\text { Calc'd } \\
\% \\
\text { Yield }\end{array}$ & MS & IR \\
\hline Benzaldehyde & $l$-PAC & $4-\mathrm{H}$ & $41.5 \%$ & $\begin{array}{c}150 \\
107 \\
79,77 \\
51,43\end{array}$ & $\begin{array}{c}2866 \text { (vC-H al), } 1365(\delta \mathrm{C}-\mathrm{H} \text { al }), 3035 \\
\text { (vC-H ar), } 3074(\mathrm{vC}-\mathrm{H} \text { ar }), 1730 \\
(\mathrm{vC}=\mathrm{O}), 3442(2 \mathrm{vC}=\mathrm{O}), 3508(\mathrm{vO}-\mathrm{H}), \\
1176(\mathrm{vC}-\mathrm{OH}), 3651(\mathrm{vOH}: \mathrm{O}=\mathrm{C})\end{array}$ \\
\hline $\begin{array}{c}3,4- \\
\text { Methylenedioxy }\end{array}$ & $\begin{array}{c}\text { 1-Hydroxy-1- } \\
{[3,4-} \\
\text { (methylenedioxy) } \\
\text { phenyl]-2- } \\
\text { propanone* }\end{array}$ & $\begin{array}{c}3,4- \\
\mathrm{CH}_{2} \mathrm{OCH}_{2}\end{array}$ & $12.8 \%$ & $\begin{array}{c}194 \\
151 \\
123 \\
93,65 \\
43\end{array}$ & $\begin{array}{l}2877(\mathrm{vC}-\mathrm{H} \text { al }), 2918(\mathrm{vC}-\mathrm{H} \text { al }), 2981 \\
\text { (vC-H al), } 1362(\delta \mathrm{C}-\mathrm{H} \text { al), } 3018(\mathrm{vC}-\mathrm{H} \\
\text { ar), } 3074(\mathrm{vC}-\mathrm{H} \text { ar}), 1730(\mathrm{vC}=\mathrm{O}), \\
3426(2 \mathrm{vC}=\mathrm{O}), 3506(\mathrm{vO}-\mathrm{H}), 1174 \\
\text { (vC-OH), } 3654(\mathrm{vOH}: \mathrm{O}=\mathrm{C}), 1049(\mathrm{vC}- \\
\text { O-C of methylenedioxy group), } 2777 \\
\text { (vC-H of methylenedioxy group) }\end{array}$ \\
\hline 4-Methoxy & $\begin{array}{l}\text { 1-Hydroxy-1-(4- } \\
\text { methoxyphenyl)- } \\
\text { 2-propanone* }\end{array}$ & $4-\mathrm{OCH}_{3}$ & $20.4 \%$ & $\begin{array}{c}180 \\
137 \\
109 \\
94,77 \\
43\end{array}$ & $\begin{array}{c}2949(\mathrm{vC}-\mathrm{H} \text { al }), 1363(\delta \mathrm{C}-\mathrm{H} \text { al }), 3008 \\
(\mathrm{vC}-\mathrm{H} \text { ar }), 3074(\mathrm{vC}-\mathrm{H} \text { ar }), 1728 \\
(\mathrm{vC}=\mathrm{O}), 3437(2 \mathrm{vC}=\mathrm{O}), 3508(\mathrm{vO}-\mathrm{H}), \\
3653(\mathrm{vOH}: \mathrm{O}=\mathrm{C}), 1174(\mathrm{vC}-\mathrm{OH}), 1252 \\
(\mathrm{vAryl}-\mathrm{O}), 1041\left(\mathrm{vO}-\mathrm{CH}_{3}\right), 2920(\mathrm{vC}- \\
\left.\mathrm{H}^{\circ} \mathrm{OCH}_{3}\right), 2846\left(2 \delta \mathrm{C}-\mathrm{H} \text { of } \mathrm{OCH}_{3}\right)\end{array}$ \\
\hline 4-Fluoro & $\begin{array}{l}\text { 1-(4- } \\
\text { Fluorophenyl)-1- } \\
\text { hydroxy-2- } \\
\text { propanone }\end{array}$ & $4-\mathrm{F}$ & $29.2 \%$ & $\begin{array}{c}168, \\
125, \\
97,95, \\
77,43\end{array}$ & $\begin{array}{c}2868(\mathrm{vC}-\mathrm{H} \text { al }), 2927(\mathrm{vC}-\mathrm{H} \text { al }), 1365 \\
(\delta \mathrm{C}-\mathrm{H} \text { al }), 3014(\mathrm{vC}-\mathrm{H} \text { ar }), 3047(\mathrm{vC}-\mathrm{H} \\
\text { ar), } 1730(\mathrm{vC}=\mathrm{O}), 3446(2 \mathrm{vC}=\mathrm{O}), 3505 \\
(\mathrm{vO}-\mathrm{H}), 3651(\mathrm{vOH}: \mathrm{O}=\mathrm{C}), 1161(\mathrm{vC}- \\
\text { OH), } 1178(\mathrm{vC}-\mathrm{F})\end{array}$ \\
\hline 4-Methyl & $\begin{array}{l}\text { 1-Hydroxy-1-(4- } \\
\text { methylphenyl)-2- } \\
\text { propanone }\end{array}$ & 4- $\mathrm{CH}_{3}$ & $21.3 \%$ & $\begin{array}{c}164, \\
121, \\
93,91 \\
77,65 \\
43\end{array}$ & $\begin{array}{c}2872(\mathrm{vC}-\mathrm{H} \text { al }), 2933(\mathrm{vC}-\mathrm{H} \text { al }), 1363 \\
(\delta \mathrm{C}-\mathrm{H} \text { al }), 3028(\mathrm{vC}-\mathrm{H} \text { ar }), 1730 \\
(\mathrm{vC}=\mathrm{O}), 3446(2 \mathrm{vC}=\mathrm{O}), 3508(\mathrm{vO}-\mathrm{H}), \\
3651(\mathrm{vOH}: \mathrm{O}=\mathrm{C}), 1176(\mathrm{vC}-\mathrm{OH})\end{array}$ \\
\hline 4-Methylthio & $\begin{array}{l}\text { 1-Hydroxy-1-(4- } \\
\text { (methylthio)- } \\
\text { phenyl)-2- } \\
\text { propanone }\end{array}$ & $4-\mathrm{SCH}_{3}$ & $29.8 \%$ & $\begin{array}{l}196 \\
153 \\
151 \\
109 \\
77,43\end{array}$ & $\begin{array}{c}2933(\mathrm{vC}-\mathrm{H} \text { al }), 2995(\mathrm{vC}-\mathrm{H} \text { al }), 1365 \\
(\delta \mathrm{C}-\mathrm{H} \text { al }), 3026(\mathrm{vC}-\mathrm{H} \text { ar }), 3080(\mathrm{vC}-\mathrm{H} \\
\text { ar }), 1730(\mathrm{vC}=\mathrm{O}), 3442(2 \mathrm{vC}=\mathrm{O}), 3506 \\
(\mathrm{vO}-\mathrm{H}), 3651(\mathrm{vOH}: \mathrm{O}=\mathrm{C}), 1176(\mathrm{vC}- \\
\mathrm{OH}), 2866\left(\mathrm{vS}-\mathrm{CH}_{3}\right), 1325\left(\delta \mathrm{S}-\mathrm{CH}_{3}\right)\end{array}$ \\
\hline
\end{tabular}


* Structure(s) assigned by GC-MS

The fermentation product compound assignments were confirmed through ${ }^{1} \mathrm{H}$ and ${ }^{13} \mathrm{C}$ NMR analysis:

\subsubsection{4-Fluoro Analogue of $l$-PAC}
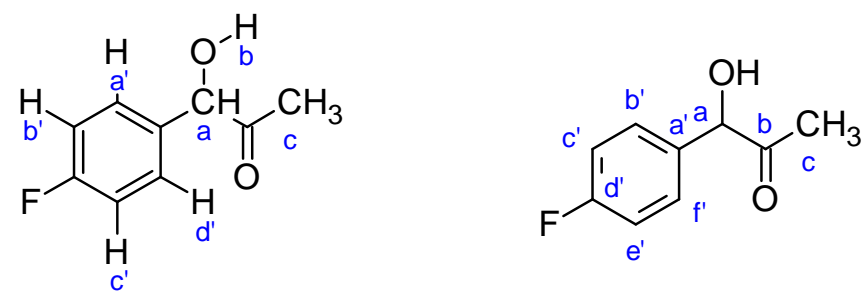

Figure 1: The protons (left) and the carbons (right) of the 4-fluoro analogue of $l$-PAC.

${ }^{1} \mathrm{H}$ NMR (400 MHz, DMSO- $\left.d_{6}\right) \delta$ 7.38-7.28 (m, 2H, Ha', Hd'), 7.05-6.91 (m, 2H, Hb', Hc'), 5.63 (d, J= 4.3 Hz, 1H, Hb), 4.99 (d, J= 4.2 Hz, 1H, Ha), 3.19 (s, $\mathrm{H}_{2} \mathrm{O}$ ), $2.00(\mathrm{~s}, 3 \mathrm{H}, \mathrm{Hc})$;

${ }^{13}$ C NMR (100 MHz, DMSO- $\left.d_{6}\right) \quad \delta 207.88(\mathrm{Cb}), 161.87$ (d, J= 245.6, Cd'), 134.81 (Ca'), $128.30\left(\mathrm{Cb}^{\prime}, \mathrm{Cf}^{\prime}\right), 115.06\left(\mathrm{Cc}^{\prime}, \mathrm{Ce}^{\prime}\right), 78.43(\mathrm{Ca}), 24.7(\mathrm{Cc})$ (refer to Figure 1 for proton and carbon labels).

\subsubsection{4-Methyl Analogue of $l$-PAC}<smiles>CC(=O)[C@H](O)c1cccc(C)c1</smiles>

Figure 2: The protons of the 4-methyl analogue of 1-PAC.

To confirm the production of 4-methyl-PAC 22, the sample which was purified via the bisulfite adduct method was analysed by ${ }^{1} \mathrm{H}$ NMR; ${ }^{1} \mathrm{H}$ NMR (400 MHz, DMSO$\left.d_{6}\right) \delta$ 7.20-7.11 (m, 2H, Ha', Hd'), 7.11-6.99 (m, 2H, Hb', Hc'), 5.14 (d, J= 4.3 Hz, $1 \mathrm{H}, \mathrm{Hb}), 4.95(\mathrm{~d}, \mathrm{~J}=4.2 \mathrm{~Hz}, 1 \mathrm{H}, \mathrm{Ha}), 2.25$ (s, 3H, Hd), 1.98 (s, 3H, Hc) (refer to Figure 2 for proton labels). A gCOSY (gradient correlation spectroscopy) spectrum was also obtained to confirm the assignment of each proton signal.

\subsubsection{4-Methylthio Analogue of $l$-PAC}



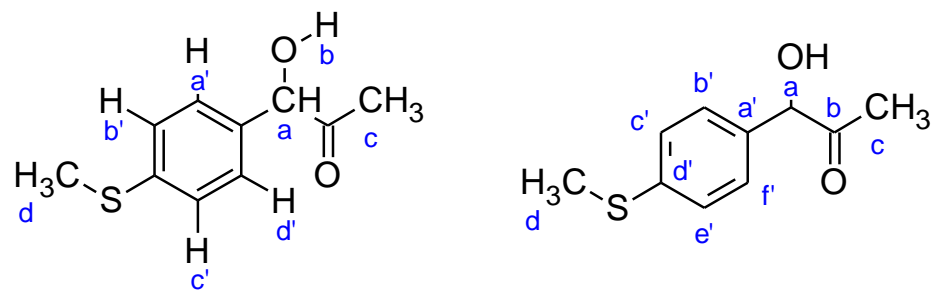

Figure 3: The protons (left) and the carbons (right) of the 4-methylthio analogue of $l$-PAC.

${ }^{1} \mathrm{H}$ NMR (400 MHz, DMSO-d $\left.{ }_{6}\right) \delta$ 7.24-7.20 (m, 2H, Ha', Hd'), 7.18-7.08 (m, 2H, $\left.\mathrm{Hb}^{\prime}, \mathrm{Hc}^{\prime}\right), 5.28$ (d, J= 4.2, 1H, Hb), 4.95 (d, J= 4.0 Hz, 1H, Ha), 2.39 (s, 3H, Hd), 1.99 (s, 3H, Hc);

${ }^{13} \mathrm{C}$ NMR (100 MHz, DMSO-d $) \delta 138.02\left(\mathrm{Cd}^{\prime}\right), 134.94\left(\mathrm{Ca}^{\prime}\right), 126.83\left(\mathrm{Cb}^{\prime}, \mathrm{Cf}^{\prime}\right)$, $125.84\left(\mathrm{Cc}^{\prime}, \mathrm{Ce}^{\prime}\right), 78.93(\mathrm{Ca}), 24.58(\mathrm{Cc}), 14.91(\mathrm{Cd})$ (refer to Figure 3 for proton and carbon labels).

An additional peak at $\delta 207$ was assigned to the carbon of the aldehyde group of 4(methylthio)benzaldehyde but was suspected to also be masking $\mathrm{Cb}$ of the 4methylthio analogue of $l$-PAC. This assignment was based upon the chemical shifts that $\mathrm{Cb}$ was found at in the previous ${ }^{13} \mathrm{C}$ NMR's of $l$-PAC and the 4-fluoro analogue of $l$-PAC. Additional peaks were also encountered in the ${ }^{1} \mathrm{H}$ NMR at $\delta 9.82,7.69$, 7.26 and 2.46 and the ${ }^{13} \mathrm{C}$ NMR at $\delta 132.25,129.37,147.31,124.57$ and 13.98 which were attributed to remaining 4-(methylthio)benzaldehyde in the sample.

A NOESY spectrum provided the through-space proton interactions of the sample and was also employed to confirm the assignment of each proton signal. This therefore enabled confirmation of the successful production of the 4-methylthio analogue of $l$-PAC from the biotransformation of 4-(methylthio)benzaldehyde.

The bisulfite adduct purification technique employed for the purification of the fermentation products was accompanied by a number of problems such as loss of large amounts of starting material and carryover of substituted benzaldehyde. As a result, samples pure enough for NMR analysis could not be obtained for the 3,4methylenedioxybenzaldehyde and 4-methoxybenzaldehyde fermentation products. 
The assignment of these compounds was therefore made using GC-MS and GC-IRD analysis.

Throughout the fermentations, full conversion of the substituted benzaldehydes to the corresponding $l$-PAC analogue proved difficult due to competing side reactions. Unlike benzaldehyde, the substituted benzaldehydes all produced fermentation products with anywhere between 5-30\% (GC-MS relative yield) substituted benzaldehyde.

Shin and Rogers ${ }^{7}$ had previously reported that a $60-70 \%$ conversion of benzaldehyde to $l$-PAC could be obtained when using a sophisticated fermentation set-up employing partially purified pyruvate decarboxylase and immobilized yeast cells. Using the basic fermentation method employed during this project, which was designed to mimic a clandestine process, the fermentation of benzaldehyde, 4methoxybenzaldehyde, 4-fluorobenzaldehyde, 4-methylbenzaldehyde, 4(methylthio)benzaldehyde appeared to be reasonable yielding reactions with conversion rates of $42 \%, 20 \%, 29 \%, 21 \%$ and $30 \%$ respectively. Conversely, the fermentation of 3,4-methylenedioxybenzaldehyde was only a low yielding reaction (13\%), attributed to an increased sensitivity of the yeast to 3,4methylenedioxybenzaldehyde. However, the activity of alcohol dehydrogenase, demonstrated by the production of 3,4-methylenedioxybenzyl alcohol implies that the yeast was not killed during the fermentations. This would indicate that rather than poisoning the yeast, 3,4-methylenedioxybenzaldehyde could not be utilized as efficiently as the other substituted benzaldehydes.

\subsection{Reductive Amination}

The results of the reductive amination of each of the crude $l$-PAC analogue samples appear in Table 6. 
Table 6: The pseudoephedrine/ephedrine analogues formed following reductive amination of the corresponding $l$-PAC analogue.

\begin{tabular}{|c|c|c|c|c|c|}
\hline $\begin{array}{c}l \text {-PAC } \\
\text { Analogue } \\
\text { Reductively } \\
\text { Aminated }\end{array}$ & $\begin{array}{l}\text { Pseudoephedrine/ } \\
\text { ephedrine Analogue } \\
\text { Produced }\end{array}$ & $\mathrm{R}_{1}$ & $\begin{array}{l}\text { Calc'd } \\
\% \\
\text { Yield }\end{array}$ & MS & IR \\
\hline$l$-PAC & $\begin{array}{c}\text { Pseudoephedrine/ } \\
\text { ephedrine }\end{array}$ & 4-H & $53.7 \%$ & $\begin{array}{l}164,105 \\
77,58,42\end{array}$ & $\begin{array}{c}2884 \text { (vC-H al), } 2974 \text { (vC-H } \\
\text { al), } 1381 \text { ( } \delta \mathrm{C}-\mathrm{H} \text { al }), 3033 \text { (vC- } \\
\mathrm{H} \text { ar), } 3070 \text { (vC-H ar), } 1196 \\
\text { (vC-N), } 3649 \text { (vO-H), } 3498 \\
\text { (vOH:NH), } 1068 \text { (vC-OH) }\end{array}$ \\
\hline $\begin{array}{c}3,4- \\
\text { Methylenedioxy }\end{array}$ & $\begin{array}{c}\alpha-[1- \\
\text { (Methylamino)ethyl]- } \\
\text { 1,3-benzo-dioxole-5- } \\
\text { methanol }\end{array}$ & $\begin{array}{c}3,4- \\
\mathrm{CH}_{2} \mathrm{OCH}_{2}\end{array}$ & $17.5 \%$ & $\begin{array}{c}209,149 \\
121,93 \\
58,42\end{array}$ & $\begin{array}{c}2879(\mathrm{vC}-\mathrm{H} \text { al }), 2972(\mathrm{vC}-\mathrm{H} \\
\text { al), } 1381(\delta \mathrm{C}-\mathrm{H} \text { al }), 3018(\mathrm{vC}- \\
\mathrm{H} \text { ar }), 3078(\mathrm{vC}-\mathrm{H} \text { ar}), 1188 \\
(\mathrm{vC}-\mathrm{N}), 3649(\mathrm{vO}-\mathrm{H}), 3498 \\
(\mathrm{vOH}: \mathrm{NH}), 1093(\mathrm{vC}-\mathrm{OH}), \\
1049(\mathrm{vC}-\mathrm{O}-\mathrm{C} \text { of } \mathrm{MD}), 2777 \\
\text { (vC-H of methylenedioxy } \\
\text { group) }\end{array}$ \\
\hline 4-Methoxy & $\begin{array}{c}\text { 4-Methoxy- } \alpha-[1- \\
\text { (methylamino)ethyl]- } \\
\text { benzenemethanol* }\end{array}$ & $4-\mathrm{OCH}_{3}$ & $4.5 \%$ & $\begin{array}{l}195,137 \\
109,107 \\
77,58,51\end{array}$ & $\begin{array}{c}2804(\mathrm{vC}-\mathrm{H} \text { al }), 2964(\mathrm{vC}-\mathrm{H} \\
\mathrm{al}), 1379(\delta \mathrm{C}-\mathrm{H} \text { al }), 3005(\mathrm{vC}- \\
\mathrm{H} \text { ar), } 3072(\mathrm{vC}-\mathrm{H} \text { ar}), 1173 \\
(\mathrm{vC}-\mathrm{N}), 3649(\mathrm{vO}-\mathrm{H}), 3502 \\
(\mathrm{vOH}: \mathrm{NH}), 1041(\mathrm{vC}-\mathrm{OH}), \\
1248(\mathrm{vAryl}-\mathrm{O}), 1041(\mathrm{vO}- \\
\left.\mathrm{CH}_{3}\right), 2914\left(\mathrm{vC}-\mathrm{H} \text { of } \mathrm{OCH}_{3}\right), \\
2846\left(2 \delta \mathrm{C}-\mathrm{H} \text { of } \mathrm{OCH}_{3}\right)\end{array}$ \\
\hline 4-Fluoro & $\begin{array}{c}\text { 4-Fluoro- } \alpha-[1- \\
\text { (methylamino)ethyl]- } \\
\text { benzenemethanol* }\end{array}$ & $4-\mathrm{F}$ & $53.2 \%$ & $\begin{array}{c}184,164, \\
125,123, \\
97,95, \\
77,58,51\end{array}$ & $\begin{array}{c}2893(\mathrm{vC}-\mathrm{H} \text { al }), 2978 \text { (vC-H } \\
\text { al), } 1383 \text { ( } \delta \mathrm{C}-\mathrm{H} \text { al }), 3043 \text { (vC- } \\
\mathrm{H} \text { ar), } 3078(\mathrm{vC}-\mathrm{H} \text { ar }), 3651 \\
(\mathrm{vO}-\mathrm{H}), 3496(\mathrm{vOH}: \mathrm{NH}), 1080 \\
(\mathrm{vC}-\mathrm{OH}), 1122(\mathrm{vC}-\mathrm{N}), 1157 \\
\text { (vC-F) }\end{array}$ \\
\hline 4-Methyl & $\begin{array}{c}\text { 4-Methyl- } \alpha-[1- \\
\text { (methylamino)ethyl]- } \\
\text { benzenemethanol* }\end{array}$ & 4- $\mathrm{CH}_{3}$ & $60.3 \%$ & $\begin{array}{l}180,162 \\
146,121 \\
119,93 \\
91,77 \\
65,58,51\end{array}$ & $\begin{array}{c}2879(\mathrm{vC}-\mathrm{H}), 2935(\mathrm{vC}-\mathrm{H}), \\
1381(\delta \mathrm{C}-\mathrm{H} \text { al), } 2974(\mathrm{vC}-\mathrm{H} \\
\text { ar), } 3024(\mathrm{vC}-\mathrm{H} \text { ar }), 3649(\mathrm{vO}- \\
\mathrm{H}), 1178(\mathrm{vC}-\mathrm{N}), 3500 \\
(\mathrm{vOH}: \mathrm{NH}), 1078(\mathrm{vC}-\mathrm{OH}), \\
2803\left(\mathrm{vC}-\mathrm{H} \text { of Aryl-CH }{ }_{3}\right)\end{array}$ \\
\hline
\end{tabular}




\begin{tabular}{|c|c|c|c|c|c|}
\hline 4-Methylthio & $\begin{array}{l}\text { 4-Met-ylthio- } \alpha-[1- \\
\text { (methylamino)ethyl]- } \\
\text { benzenemethanol* }\end{array}$ & 4- $\mathrm{SCH}_{3}$ & $10.8 \%$ & $\begin{array}{l}211,194 \\
178,153 \\
151,131 \\
125,123 \\
109,77 \\
58,51\end{array}$ & $\begin{array}{c}2933(\mathrm{vC}-\mathrm{H} \text { al }), 2976 \text { (vC-H } \\
\text { al), } 1383(\delta \mathrm{C}-\mathrm{H} \text { al), } 3024 \text { (vC- } \\
\mathrm{H} \text { ar), } 3078 \text { (vC-H ar), } 1176 \\
(\mathrm{vC}-\mathrm{N}), 3649(\mathrm{vO}-\mathrm{H}), 1092 \\
(\mathrm{vC}-\mathrm{OH}), 3496(\mathrm{vOH}: \mathrm{NH}), \\
2885\left(\mathrm{vS}-\mathrm{CH}_{3}\right), 1317(\delta \mathrm{S}- \\
\left.\mathrm{CH}_{3}\right), 2804\left(\mathrm{vC}-\mathrm{H} \text { of } \mathrm{SCH}_{3}\right)\end{array}$ \\
\hline
\end{tabular}

In each reductive amination where the crude $l$-PAC analogue used contained substituted benzaldehyde, the corresponding $N$-methyl-benzylamine analogue was produced, formed through the amination of residual benzyl alcohol. The presence of $N$-methyl-benzylamine analogues can be used as an indicative marker that the product was synthesised from an initial substituted benzaldehyde fermentation followed by reductive amination.

According to the literature ${ }^{8}$ the reductive amination of $l$-PAC should produce a conversion of $79 \%$-PAC to pseudoephedrine/ephedrine. Therefore, the reductive amination of $l$-PAC and the 4-fluoro and 4-methyl analogues of $l$-PAC appeared to be reasonable yielding reactions with conversion rates of $54 \%, 53 \%$ and $60 \%$ respectively. Conversely, the reductive amination of the 3,4-methylenedioxy, 4methoxy and 4-methylthio analogues of $l$-PAC were low yielding reactions (17\%, $4.5 \%$ and $11 \%$ respectively).

\subsection{Hypophosphorous Acid Reduction}

The results of the hypophosphorous acid reduction of each of the crude pseudoephedrine/ephedrine analogue samples appear in Table 7. 
Table 7: The methylamphetamine analogues formed following reduction of the corresponding pseudoephedrine/ephedrine analogue.

\begin{tabular}{|c|c|c|c|c|c|}
\hline $\begin{array}{l}\text { Pseudoephedrine/ } \\
\text { ephedrine analogue } \\
\text { reduced }\end{array}$ & $\begin{array}{c}\text { Methylamphetamine } \\
\text { Analogue } \\
\text { Produced }\end{array}$ & $\mathrm{R}_{1}$ & $\begin{array}{l}\text { Calc'd \% } \\
\text { Yield }\end{array}$ & MS & IR \\
\hline $\begin{array}{l}\text { Pseudoephedrine/ep } \\
\text { hedrine }\end{array}$ & Methylamphetamine & $4-\mathrm{H}$ & $14.9 \% * *$ & $\begin{array}{c}148,134,115 \\
91,77,58\end{array}$ & $\begin{array}{c}2860 \text { (vC-H al), } 2933 \\
\text { (vC-H al), } 2970 \text { (vC-H } \\
\text { al), } 1377 \text { ( } \delta \mathrm{C}-\mathrm{H} \text { al), } \\
3032 \text { (vC-H ar), } 3070 \\
\text { (vC-H ar), } 1151(\mathrm{vC}-\mathrm{N})\end{array}$ \\
\hline $\begin{array}{c}\text { 3,4- } \\
\text { Methylenedioxy }\end{array}$ & $\begin{array}{c}\mathrm{N}, \alpha \text {-Dimethyl-1,3- } \\
\text { benzodioxole-5- } \\
\text { ethanamine* }\end{array}$ & $\begin{array}{c}3,4- \\
\mathrm{CH}_{2} \mathrm{O} \\
\mathrm{CH}_{2}\end{array}$ & $1.4 \%$ & $\begin{array}{c}178,160,135 \\
105,77,58\end{array}$ & Insufficient quantity \\
\hline 4-Methoxy & $\begin{array}{c}\text { 4-Methoxy- } N, \alpha- \\
\text { dimethylbenzeneeth } \\
\text { anamine* }\end{array}$ & $\begin{array}{c}4- \\
\mathrm{OCH}_{3}\end{array}$ & $4.8 \%$ & $\begin{array}{c}178,148,121 \\
103,78,58\end{array}$ & Insufficient quantity \\
\hline 4-Fluoro & $\begin{array}{c}\text { 4-Fluoro- } N, \alpha- \\
\text { dimethyl- } \\
\text { benzeneethanamine }\end{array}$ & $4-\mathrm{F}$ & $57.7 \%$ & $\begin{array}{c}166,152,133 \\
109,83,58\end{array}$ & $\begin{array}{c}2800(\mathrm{vC}-\mathrm{H} \text { al }), 2860 \\
(\mathrm{vC}-\mathrm{H} \text { al), } 2935(\mathrm{vC}-\mathrm{H} \\
\text { al), } 2971(\mathrm{vC}-\mathrm{H} \text { al), } \\
1377(\delta \mathrm{C}-\mathrm{H} \text { al }), 3043 \\
(\mathrm{vC}-\mathrm{H} \text { ar), } 3074(\mathrm{vC}-\mathrm{H} \\
\text { ar), } 1155(\mathrm{vC}-\mathrm{F}), \\
\text { vC-N masked by vC-F }\end{array}$ \\
\hline 4-Methyl & $\begin{array}{l}\mathrm{N}, \alpha, 4-\text { Trimethyl- } \\
\text { benzeneethanamine }\end{array}$ & $\begin{array}{c}4- \\
\mathrm{CH}_{3}\end{array}$ & $33.3 \%$ & $\begin{array}{c}162,148,105 \\
77,58\end{array}$ & $\begin{array}{c}2881 \text { (vC-H al), } 2931 \\
(\mathrm{vC}-\mathrm{H} \text { al }), 2972(\mathrm{vC}-\mathrm{H} \\
\mathrm{al}), 1375(\delta \mathrm{C}-\mathrm{H} \text { al }), \\
3022(\mathrm{vC}-\mathrm{H} \text { ar}), 3049 \\
(\mathrm{vC}-\mathrm{H} \text { ar}), 1149(\mathrm{vC}-\mathrm{N}), \\
2798(\mathrm{vC}-\mathrm{H} \text { of Aryl- } \\
\left.\mathrm{CH}_{3}\right)\end{array}$ \\
\hline 4-Methylthio & $\begin{array}{c}\mathrm{N}, \alpha \text {-Dimethyl-4- } \\
\text { (methylthio)- } \\
\text { benzeneethanamine } \\
*\end{array}$ & $\begin{array}{c}4- \\
\mathrm{SCH}_{3}\end{array}$ & $32.0 \%$ & $\begin{array}{c}194,180,164, \\
137,121,91,77, \\
63,58,51\end{array}$ & $\begin{array}{c}2931 \text { (vC-H al), } 2972 \\
(\mathrm{vC}-\mathrm{H} \text { al), } 1377(\delta \mathrm{C}-\mathrm{H} \\
\text { al), } 3024(\mathrm{vC}-\mathrm{H} \text { ar }), \\
3074(\mathrm{vC}-\mathrm{H} \text { ar }), 1149 \\
(\mathrm{vC}-\mathrm{N}), 2858\left(\mathrm{vS}-\mathrm{CH}_{3}\right), \\
1342\left(\delta \mathrm{S}-\mathrm{CH}_{3}\right), 2800 \\
\left(\mathrm{vC}-\mathrm{H} \text { of } \mathrm{SCH}_{3}\right)\end{array}$ \\
\hline
\end{tabular}


Production of the 4-fluoro analogue of methylamphetamine was confirmed through ${ }^{1} \mathrm{H}$ and ${ }^{13} \mathrm{C}$ NMR analysis;
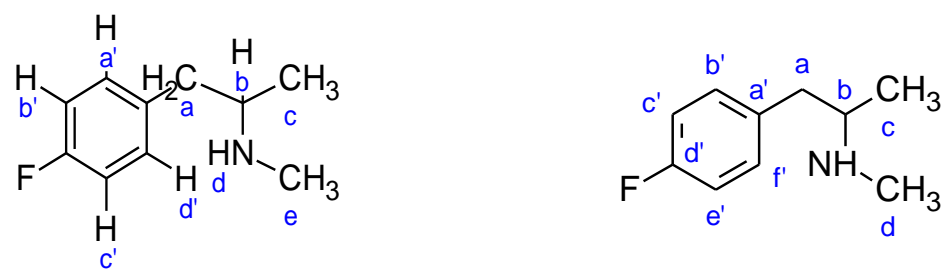

Figure 4: The protons (left) and the carbons (right) of the 4-fluoro analogue of methylamphetamine.

${ }^{1} \mathrm{H}$ NMR (400 MHz, DMSO-d $\left.d_{6}\right) \delta$ 3.14-3.05 (m, 1H, Hb), 3.03-2.55 (m, 2H, Ha), $2.48(\mathrm{~s}, 3 \mathrm{H}, \mathrm{He}), 1.07$ (d, J=6.3 Hz, 3H, Hc); ${ }^{13} \mathrm{C}$ NMR (100 MHz, DMSO-d $) \delta$ 162.76-159.75 (Cd'), $132.72\left(\mathrm{Ca}^{\prime}\right), 130.39\left(\mathrm{Cb}^{\prime}, \mathrm{Cf}^{\prime}\right), 114.86$ (Cc', Ce'), $55.69(\mathrm{Cb})$, $31.13(\mathrm{Cd}), 16.18(\mathrm{Cc})$ (refer to Figure 4 for proton and carbon labels).

A proton signal for proton $\mathrm{d}$ was not observed in the ${ }^{1} \mathrm{H}$ NMR spectrum. It is proposed that this signal would have been present at approximately 9-10 ppm, however, this cannot be confirmed as this region was not viewable in the ${ }^{1} \mathrm{H}$ NMR spectrum.

The shifts assigned to the aromatic proton signals would also have been contributed to by the aromatic protons of $N$-methyl-4-fluorobenzylamine. It was extremely difficult to separate the signals of these two compounds due to their overlapping nature. Therefore $\delta$ in the region of 7.37-6.83 were attributed to the aromatic H's of both 4-fluoromethamphetamine and $N$-methyl-4-fluorobenzylamine.

\subsection{Acid Dichromate Oxidation}

The results of the acid dichromate oxidation of each of the crude pseudoephedrine/ephedrine analogue samples appear in Table 8. 
Table 8: The methcathinone analogues formed following oxidation of the corresponding pseudoephedrine/ephedrine analogue.

\begin{tabular}{|c|c|c|c|c|c|}
\hline $\begin{array}{l}\text { Pseudoephedrine/ } \\
\text { ephedrine analogue } \\
\text { reduced }\end{array}$ & $\begin{array}{l}\text { Methcathinone } \\
\text { Analogue } \\
\text { Produced }\end{array}$ & $\mathrm{R}_{1}$ & $\begin{array}{l}\text { Calc'd } \\
\% \text { Yield }\end{array}$ & MS & IR \\
\hline $\begin{array}{l}\text { Pseudoephedrine/ } \\
\text { ephedrine }\end{array}$ & Methcathinone & $4-\mathrm{H}$ & $5.4 \% * *$ & $\begin{array}{c}163 \\
133 \\
105,77 \\
58\end{array}$ & $\begin{array}{l}2806 \text { (vC-H al), } 2898 \\
\text { (vC-H al), } 2947 \text { (vC-H } \\
\text { al), } 1375(\delta \mathrm{C}-\mathrm{H} \text { al), } 2983 \\
\text { (vC-H ar), } 3037(\mathrm{vC}-\mathrm{H} \\
\text { ar), } 3072(\mathrm{vC}-\mathrm{H} \text { ar), } 1180 \\
\text { (vC-N), } 1699(\mathrm{vC}=\mathrm{O})\end{array}$ \\
\hline 3,4-Methylenedioxy & $\begin{array}{l}\text { 2-Methylamino-1-(3,4- } \\
\text { methylenedioxyphenyl)- } \\
\text { propan-1-one* }\end{array}$ & $\begin{array}{c}3,4- \\
\mathrm{CH}_{2} \mathrm{OCH}_{2}\end{array}$ & $0.8 \%$ & $\begin{array}{c}207, \\
176, \\
149, \\
121,91, \\
58\end{array}$ & Insufficient quantity \\
\hline 4-Methoxy & $\begin{array}{c}\text { 1-(4-Methoxyphenyl)-2- } \\
\text { (methylamino)-1- } \\
\text { propanone }\end{array}$ & $4-\mathrm{OCH}_{3}$ & $93.1 \%$ & $\begin{array}{c}135 \\
107,92 \\
77,64 \\
58\end{array}$ & $\begin{array}{c}2806(\mathrm{vC}-\mathrm{H} \text { al }), 2976 \\
\text { (vC-H al), } 1373(\delta \mathrm{C}-\mathrm{H} \\
\text { al), } 3010(\mathrm{vC}-\mathrm{H} \text { ar }), 3078 \\
(\mathrm{vC}-\mathrm{H} \text { ar }), 1171(\mathrm{vC}-\mathrm{N}), \\
1693(\mathrm{vC}=\mathrm{O}), 3371 \\
(2 \mathrm{vC}=\mathrm{O}), 1255(\mathrm{vAryl}- \\
\mathrm{O}), 1039\left(\mathrm{vO}-\mathrm{CH}_{3}\right), 2945 \\
\left(\mathrm{vC}-\mathrm{H} \text { of } \mathrm{OCH}_{3}\right), 2850 \\
\left(2 \delta \mathrm{C}-\mathrm{H} \text { of } \mathrm{OCH}_{3}\right)\end{array}$ \\
\hline 4-Fluoro & $\begin{array}{l}\text { 4-Fluoro- } N, \alpha \text {-dimethyl- } \\
\text { benzeneethanamine }\end{array}$ & $4-\mathrm{F}$ & $80.2 \%$ & $\begin{array}{c}166 \\
146 \\
123,95 \\
58\end{array}$ & $\begin{array}{c}2881(\mathrm{vC}-\mathrm{H} \text { al }), 2947 \\
(\mathrm{vC}-\mathrm{H} \text { al }), 1265(\delta \mathrm{C}-\mathrm{H} \\
\text { al), } 2960(\mathrm{vC}-\mathrm{H} \text { ar }), 2979 \\
(\mathrm{vC}-\mathrm{H} \text { ar }), 1138(\mathrm{vC}-\mathrm{N}), \\
1699(\mathrm{vC}=\mathrm{O}), 1155(\mathrm{vC}- \\
\mathrm{F})\end{array}$ \\
\hline 4-Methyl & $\begin{array}{l}\text { 2-(Methylamino)-1-(4- } \\
\text { methylphenyl)-1- } \\
\text { propanone }\end{array}$ & 4- $\mathrm{CH}_{3}$ & $88.3 \%$ & $\begin{array}{c}162 \\
143 \\
119,91 \\
58\end{array}$ & $\begin{array}{c}2885 \text { (vC-H al), } 2937 \\
\text { (vC-H al), } 1375(\delta \mathrm{C}-\mathrm{H} \\
\text { al), } 2978(\mathrm{vC}-\mathrm{H} \text { ar), } 3033 \\
\text { (vC-H ar), } 1178(\mathrm{vC}-\mathrm{N}), \\
1697(\mathrm{vC}=\mathrm{O}), 2806(\mathrm{vC}- \\
\left.\quad \mathrm{H} \text { of Aryl- } \mathrm{CH}_{3}\right)\end{array}$ \\
\hline 4-Methylthio & $\begin{array}{l}\text { 2-(Methylamino)-1-[4- } \\
\text { (methylthio)phenyl]-1- } \\
\text { propanone }\end{array}$ & 4-SCH & - & - & - \\
\hline
\end{tabular}


Production of the 4-fluoro analogue of methcathinone was confirmed through ${ }^{1} \mathrm{H}$ and ${ }^{13} \mathrm{C}$ NMR analysis:<smiles>CNC(C)C(=O)c1ccccc1</smiles><smiles>CNC(C)C(=O)c1ccc(F)cc1</smiles>

Figure 5: The protons (left) and the carbons (right) of the 4-fluoro analogue of methcathinone

${ }^{1} \mathrm{H}$ NMR (400 MHz, DMSO-d $\left.)\right) \delta 9.69$ (s, 1H, Hc), 8.07-7.97 (m, 2H, Ha', Hd'), 7.27-7.14 (m, 2H, Hb', Hc'), 5.05 (dt, J= 7.3, 5.9 Hz, 1H, Ha), 2.57 (q, J= 4.6, 3.9 Hz, $3 \mathrm{H}, \mathrm{Hd}), 1.47$ (d, J= 7.2 Hz, 3H, Hb);

${ }^{13} \mathrm{C}$ NMR (100 MHz, DMSO- $\left.d_{6}\right) \delta 194.08(\mathrm{Ca}), 167.08\left(\mathrm{Cd}^{\prime}\right), 131.43\left(\mathrm{Cb}^{\prime}, \mathrm{Cf}^{\prime}\right)$, $129.06\left(\mathrm{Ca}^{\prime}\right), 115.89$ (Cc', Ce'), $58.18(\mathrm{Cb}), 30.64(\mathrm{Cd}), 15.38(\mathrm{Cc})$ (refer to Figure 5 for proton and carbon labels). A number of additional small peaks were also observed in the ${ }^{1} \mathrm{H}$ NMR and were attributed to impurities such as $N$-methyl-4fluorobenzylamine.

Production of the 4-methyl analogue of methcathinone was confirmed through ${ }^{1} \mathrm{H}$ NMR analysis;<smiles>CNC(C)C(=O)c1ccccc1</smiles>

Figure 6: The protons of the 4-methyl analogue of methcathinone.

${ }^{1} \mathrm{H}$ NMR (400 MHz, DMSO-d $\left.d_{6}\right) \delta$ 9.32-9.22 (m, 1H, Hc), $7.79(\mathrm{~d}, \mathrm{~J}=8.2 \mathrm{~Hz}, 2 \mathrm{H}$, either $\mathrm{Ha}^{\prime}$ and $\mathrm{Hd}^{\prime}$ or $\mathrm{Hb}^{\prime}$ and $\left.\mathrm{Hc}^{\prime}\right), 7.22$ (d, J=8.0 Hz, 2H, either $\mathrm{Ha}^{\prime}$ and $\mathrm{Hd}^{\prime}$ or $\mathrm{Hb}^{\prime}$ and $\mathrm{Hc}^{\prime}$ ), 4.99 (q, J=6.5 Hz, 1H, Ha), 2.59 (q, J= 6.4, $\left.5.8 \mathrm{~Hz}, 3 \mathrm{H}, \mathrm{Hd}\right), 2.31$ (s, 3H, $\mathrm{He}), 1.49$ (d, J=7.0 Hz, 3H, Hb) (refer to Figure 6 for proton labels ). 
Shifts at 6.80, 3.81 and 1.01, and 9.45, 7.34, 7.07, 3.95, 2.46 and 2.21 were also observed in the ${ }^{1} \mathrm{H}$ NMR, attributed to isopropyl alcohol and $N$-methyl-4methylbenzylamine.

A United Nations Office on Drugs and Crime publication, Amphetamines and Ecstasy: 2011 Global ATS Assessment ${ }^{9}$, reported that the hypophosphorous acid reduction of pseudoephedrine/ephedrine generally produces a percentage yield of $76 \%$ methylamphetamine whilst the oxidation of pseudoephedrine/ephedrine employing potassium permanganate generally produces a percentage yield of $50 \%$ methcathinone. In comparison, the reduction and oxidation of the 4-fluoro and 4methyl analogues of pseudoephedrine/ephedrine appeared to be reasonable yielding reactions with conversion rates of $33 \%$ and higher. On the other hand, the reduction and oxidation of the 3,4-methylenedioxy analogue were poor yielding reactions with conversion rates of just $1 \%$ for each. In the case of the 4-methoxy pseudoephedrine/ephedrine analogue it was found to produce a reasonable yield of the 4-methoxy methcathinone analogue (93\%) but was not suited for the reduction reaction (5\%). Conversely, the 4-methylthio analogue produced a reasonable yield of the 4-methylthio methamphetamine analogue $(32 \%)$ but the oxidation of which appeared to be unsuccessful.

It was anticipated that difficulties would be had during the reduction of the 3,4methylenedioxy and 4-methoxy analogues of pseudoephedrine/ephedrine due to the tendency of hydriodic acid to cleave ethers and less commonly thioethers. An absence of the expected hydroxyl substituted methylamphetamine products was attributed due to deprotonation during basification and subsequent loss during extraction.

\subsection{Conclusion}

The fermentation of the substituted benzaldehydes was found to be a viable route for the production of the corresponding $l$-PAC analogues, except in the case of 3,4methylenedioxybenzaldehyde. Reductive amination of these $l$-PAC analogues was able to generate viable amounts of the 4-fluoro and 4-methyl analogues of 
pseudoephedrine/ephedrine but was unsuccessful at producing useable quantities of the 3,4-methylenedioxy, 4-methoxy and 4-methylthio analogues.

Following reduction of the pseudoephedrine/ephedrine analogues, the hypophosphorous acid method was deemed practical for the manufacture of the 4fluoro, 4-methyl and 4-methylthio analogues of methylamphetamine and unsuited for the reduction of the 3,4-methylenedioxy and 4-methoxy analogues. When oxidised, the acid dichromate method was capable of producing viable quantities of each of the corresponding methcathinone analogues apart from the 4-methylthio analogue.

In conclusion, this manufacturing pathway was found to be a viable route for the synthesis of the 4-fluoro and 4-methyl analogues of methylamphetamine and methcathinone. Whilst a reasonable yield of the 4-methylthio analogue of methylamphetamine could be produced following reduction of the corresponding pseudoephedrine/ephedrine analogue, synthesis of the pseudoephedrine/ephedrine analogue was difficult. Therefore, this manufacturing pathway was deemed inadequate for the production of the 4-methylthio analogue of methylamphetamine and methcathinone as well as for the manufacture of the 3,4-methylenedioxy and 4methoxy analogues of methylamphetamine and methcathinone.

\section{Acknowledgments}

The authors which to acknowledge the contribution of Peter Vallely of the Australian Crime Commission for constructive comments during the development of this project, and Dr Sue Boyd of Griffith University for NMR analysis.

\section{References}

1. Neuberg, C.; Hirsch, J., An enzyme which brings about union into carbon chains (Carboligase). Biochemische Zeitschrift 1921, 115, 282-310.

2. Neuberg, C.; Liebermann, L., Carboligase II. Biochemische Zeitschrift 1921, $121,311-325$.

3. Cox, M.; Klass, G.; Koo, C., Forensic Aspects of the Biotransformation of Benzaldehyde used in the Synthesis of Methamphetamine, Part 1: Reaction Conditions, Stereochemical Outcomes, and the use of Other Substituted 
Benzaldehydes. Journal of the Clandestine Laboratory Investigating Chemists Association 2009, 19 (4), 20-37.

4. Shukla, V.; Kulkarni, P., L-Phenylacetylcarbinol (L-PAC): biosynthesis and industrial applications. World Journal of Microbiology and Biotechnology 2000, 16 (6), 499-506.

5. Neuberg, C.; Ohle, H., Carboligase IV. Biosynthetic carbon chain union in fermentation process. Biochemische Zeitschrift 1922, 128, 610-618.

6. Szendrei, K., The Chemistry of Khat. Bullentin on Narcotics 1980, XXXII (3).

7. Shin, H.; Rogers, P., Production of L-phenylacetylcarbinol (L-PAC) from Benzaldehyde Using Partially Purified Pyruvate Decarboxylase (PDC). Biotechnology and Bioengineering 1996, 49 (1), 52-62.

8. Overman, L., Organic Reactions, Volume 59. John Wiley \& Sons, Inc.: Hoboken, New Jersey, 2002.

9. UNODC, Amphetamines and Ecstasy: 2011 Global ATS Assessment. United Nations Office on Drugs and Crime, United Nations Publication, Sales No. E.11.XI.13. 